\title{
PENGELOLAAN KEUANGAN, KOMPETENSI SUMBER DAYA MANUSIA DAN STRATEGI PEMASARAN DALAM MENGUKUR KINERJA USAHA MIKRO KECIL MENENGAH (UMKM)
}

\author{
Ni Made Suindari* dan Ni Made Rai Juniariani \\ Fakultas Ekonomi dan Bisnis Universitas Warmadewa, Denpasar, Bali-Indonesia \\ *E-Mail: madesuindari87@gmail.com
}

DiPublikasi: 01/01/2020

http://dx.doi.org/10.22225/kr.11.2.1423.148-154

\begin{abstract}
To produce good performance, UMKM entrepreneurs must know how to manage their business finances. UMKM with good performance will have high competitiveness. To realize this, quality human resources are needed. In addition, in order to be able to develop SMEs, they are required to be creative and innovative in developing effective marketing strategies in order to produce good business performance. A UMKM will be difficult to develop if its business actors do not know how to market an effective product. This research aims to explore the effects of financial management, human resource competencies and marketing strategies on UMKM performance. This research uses 99 samples, namely the trade sector UMKMs that are included in the Denpasar Cooperative SMEs. Determination of the sample using the Slovin formula and the sampling technique used is simple random sampling. Data collection techniques were carried out by distributing questionnaires to the survey method. To answer the research hypothesis using analytical tools, namely multiple linear regression. The results showed that financial management, human resource competencies and marketing strategies had a positive effect on MSME performance.
\end{abstract}

Keywords: Financial management, human resources competence, marketing strategies, UMKM performance

\begin{abstract}
Abstrak
Untuk menghasilkan kinerja yang baik pelaku UMKM harus tahu bagaimana cara mengelola keuangan usahanya. UMKM dengan kinerja yang baik akan memiliki daya saing yang tinggi. Untuk mewujudkan hal itu dibutuhkan sumber daya manusia yang berkualitas. Selain itu, agar mampu berkembang pelaku UMKM dituntut untuk kreatif dan inovatif dalam menyusun strategi pemasaran yang efektif agar menghasilkan kinerja usaha yang bagus. Sebuah UMKM akan sulit berkembang jika pelaku usahanya tidak mengetahui bagaimana cara memasarkan suatu produk yang efektif. Penelitian ini bertujuan untuk menggali pengaruh pengelolaan keuangan, kompetensi sumber daya manusia dan strategi pemasaran pada kinerja UMKM. Penelitian ini menggunakan 99 sampel yaitu UMKM sektor perdagangan yang termasuk dalam UMKM binaan Koperasi Kota Denpasar. Penentuan sampel menggunakan rumus slovin dan teknik sampling yang digunakan adalah simple random sampling. Teknik pengumpulan data dilakukan dengan penyebaran kuesioner dengan metode survei. Untuk menjawab hipotesis penelitian menggunakan alat analisis yaitu regresi linear berganda. Hasil penelitian menunjukkan bahwa pengelolaan keuangan, kompetensi sumber daya manusia dan strategi pemasaran berpengaruh positif pada kinerja UMKM.
\end{abstract}

Kata Kunci: Pengelolaan keuangan, kompetensi sumber daya manusia, strategi pemasaran, kinerja UMKM

\section{PENDAhuluan}

Usaha Mikro Kecil Menengah (UMKM) mempunyai peranan penting dalam perekonomian Indonesia. Keberadaan UMKM di Indonesia sangat penting dan diperhatikan oleh pemerintah karena UMKM mampu menampung banyak tenaga kerja serta merupakan sumber penghasilan bagi masyarakat golongan ekonomi menengah kebawah. Produktifnya UMKM di suatu daerah tentu akan berimplikasi pada tersedianya lapangan pekerjaan dan tentunya akan memperkecil jumlah pengangguran yang ada. UMKM merupakan usaha yang mampu bertahan dari goncangan terbukti pada saat terjadinya krisis ekonomi dimana usaha berskala besar banyak yang mengalami kehancuran namun UMKM mampu bertahan bahkan dapat dikatakan sebagai sabuk penyelamat dari dampak krisis (Ratnawati \& Hikmah, 2013).

Keberadaan UMKM menjadi penggerak perekonomian di Bali khususnya di Kota Denpasar. Karena pentingnya keberadaan UMKM dalam perekonomian maka pemerintah Kota Denpasar melalui Dinas Koperasi dan UMKM Kota Denpasar melakukan beberapa upaya agar UMKM tersebut dapat terus berkembang. Adapun upaya yang dilakukan oleh Dinas Koperasi dan 
UMKM Kota Denpasar dalam menunjang perkembangan UMKM adalah memberikan kemudahan terhadap perijinan, membantu permodalan melalui Kredit Usaha Rakyat (KUR) serta melaksanakan monitoring dan evaluasi. Meskipun mempunyai peranan penting dalam perekonomian dan diberikan kemudahan oleh pemerintah namun mengembangkan UMKM bukanlah hal yang mudah.

Pesatnya perkembangan jumlah UMKM mengharuskan para pelaku UMKM untuk mampu bertahan dan siap bersaing dengan pelaku UMKM lainnya. Pelaku UMKM harus memperhatikan kinerja usahanya agar dapat bertahan dan unggul dalam persaingan. Kinerja adalah hasil kerja baik secara kualitas maupun kuantitas yang dicapai oleh perusahaan dalam menjalankan usahanya sesuai dengan tujuan yang telah ditetapkan. Kinerja adalah hasil seseorang secara keseluruhan selama periode tertentu di dalam melaksanakan tugas seperti standar hasil kerja, target atau sasaran atau kriteria yang telah ditentukan terlebih dahulu dan telah disepakati bersama. (Wahyudiati \& Isroah, 2018) dalam penelitiannya menyatakan kinerja merupakan hasil pekerjaan yang mempunyai hubungan kuat dengan tujuan strategis organisasi, kepuasan konsumen dan memberikan kontribusi pada ekonomi. Kinerja merupakan ukuran keberhasilan sebuah entitas usaha dalam mencapai tujuannya.

Untuk menghasilkan kinerja yang baik pelaku UMKM harus tahu bagaimana cara mengelola keuangan usahanya. Pengelolaan keuangan merupakan salah satu hal yang sering diabaikan oleh pelaku UMKM. Keterbatasan pengetahuan mereka tentang akuntansi menyebabkan mereka tidak mampu untuk mengelola keuangan dengan baik dan hal itu akan mempengaruhi kinerja usaha mereka. (Anggraeni, 2015) dalam penelitiannya menyatakan bahwa profesionalisme dalam pengelolaan keuangan akan membantu pelaku usaha terkait dengan pengelolaan usaha dimulai dari anggaran, perencanaan simpanan dana usaha serta pengetahuan dasar atas keuangan untuk mencapai tujuan keuangan usaha. Dalam mengelola sebuah usaha perlu pengelolaan keuangan yang baik agar menghasilkan kinerja yang baik pula. Jika aspek keuangan semakin baik maka kinerja UMKM akan semakin naik (Wahyudiati \& Isroah, 2018).

UMKM dengan kinerja yang baik akan memiliki daya saing yang tinggi. Untuk mewujudkan hal itu dibutuhkan sumber daya manusia yang berkualitas. Kompetensi sumber daya manusia adalah kompetensi yang berhubungan dengan pengetahuan, keterampilan, kemampuan dan karakteristik kepribadian yang berpengaruh secara langsung terhadap kinerjanya (Anwar, 2012). Kompetensi sumber daya manusia merupakan salah satu faktor yang berpengaruh pada kinerna UMKM. Hal ini dikarenakan sebuah unit usaha ditentukan oleh bagaimana individu-individu yang terlibat didalamnya mengelola usaha tersebut (Wahyudiati \& Isroah, 2018). Penelitian (Ardiana, Brahmayanti, \& Subaedi, 2010) menyatakan kualitas sumber daya manusia diperlukan terutama dibidang kompetensi sumber daya manusia seperti knowledge, skill, dan ability dalam berwirausaha. (Fibriyani \& Mufidah, 2018) dalam penelitiannya menemukan bahwa kompetensi sumber daya manusia berpengaruh positif pada kinerja UMKM. Semakin baik kompetensi sumber daya manusia maka semakin meningkat pula kinerja UMKM tersebut. Namun hasil berbeda yang ditemukan dalam penelitian (Ardiana et al., 2010) bahwa pengetahuan sumber daya manusia UKM tidak berpengaruh pada kinerja UMKM.

Perkembangan UMKM terus berkembang dikarenakan pertumbuhan ekonomi yang terus meningkat. Perkembangan ini tentunya menuntut pelaku UMKM untuk kreatif dan inovatif dalam menyusun strategi pemasaran yang efektif agar usahanya berkembang dan menghasilkan kinerja usaha yang bagus. Sebuah UMKM akan sulit untuk berkembang jika pelaku usahanya tidak mengetahui bagaimana cara memasarkan suatu produk yang efektif (Amalia, 2018). (Purwaningsih \& Kusuma, 2015) dalam penelitianya menemukan bahwa teknik pemasaran berpengaruh positif pada kinerja UMKM. Semakin bagus teknik pemasaran UMKM maka kinerja UMKM akan semakin meningkat. Hasil yang berbeda ditemukan oleh (Krisdanti \& Rodhiyah, 2016) bahwa kreativitas dan inovasi tidak berpengaruh pada kinerja UMKM.

Berdasarkan latar belakang diatas perumusan masalah dalam penelitian ini adalah apakah pengelolaan keuangan, kompentensi sumber daya manusia dan aspek pemasaran berpengaruh pada kinerja UMKM. Adapun tujuan yang diharapkan adalah penelitian ini mampu memberikan pertimbangan bagi pelaku UMKM bahwa dengan kinerja usaha yang baik, mereka akan dapat 
bertahan dan bersaing dengan pelaku usaha yang lainnya. Pelaku UMKM harus mampu mengelola keuangannya dengan baik dan memberikan perhatian pada sumber daya manusia yang dimiliki serta lebih kreatif dan inovatif dalam menyusun strategi pemasaran agar kinerja usahanya menjadi lebih bagus. Penelitian ini juga diharapkan mampu memberikan pertimbangan dan acuan bagi akademisi dalam memberikan penyuluhan dan pendampingan pada pelaku UMKM.

Grend theory yang digunakan dalam penelitian ini adalah teori sikap (theory of attitude). Sikap adalah suatu reaksi atau respon yang muncul dari seorang individu terhadap objek yang kemudian memunculkan perilaku individu terhadap objek tersebut dengan cara-cara tertentu (Azwar, 2010). (Tang \& Chen, 2008) menyatakan sikap menyangkut komponen kognitif berkaitan dengan keyakinan, sedangkan komponen afektif memiliki konotasi suka atau tidak suka. Sikap atau attitude merupakan suatu proses penilaian yang dilakukan oleh seorang individu terhadap suatu objek. Objek yang disikapi individu dapat berpa benda, manusia atau informasi. Proses penilaian seorang terhadap suatu objek dapat berupa penilaian positif dan negatif (Sarlito \& Meinarno, 2009).

Berdasarkan uraian diatas dapat disimpulkan bahwa sikap adalah suatu reaksi atau respon berupa penilaian yang muncul dari seorang individu terhadap objek. Sikap juga dapat dikatakan sebagai suatu perwujudan adanya kesadaran terhadap lingkungannya. Pembentukan sikap dipengaruhi oleh faktor dari dalam diri sesorang dan pengaruh lingkungan. Dalam penelitian ini menggunakan teori sikap karena seorang pelaku UMKM akan menentukan sikapnya dalam meningkatkan kinerja usahanya dengan melakukan berbagai cara diantaranya adalah melakukan pengelolaan keuagan yang baik, memberikan perhatian khusus pada sumber daya manusia yang membantu usahanya serta lebih kreatif dan inovatif dalam menyusun strategi pemasaran.

\section{HIPOTESIS PENELITIAN}

Pengelolaan keuangan adalah segala aktivitas yang berhubungan dengan perolehan, pendanaan dan pengelolaan aktiva dengan beberapa tujuan menyeluruh. seluruh proses tersebut dilakukan untuk mendapatkan pendapatan perusahaan dengan meminimalkan biaya, selain itu dalam penggunaan dan pengalokasian dana yang efisien dan dapat memaksimalkan nilai perusahaan. Pengelolaan keuangan sangat mempengaruhi kinerja perusahaan. (Anggraeni, 2015) dalam penelitiannya menyatakan bahwa profesionalisme dalam pengelolaan keuangan akan membantu pelaku usaha terkait dengan pengelolaan usaha dimulai dari anggaran, perencanaan simpanan dana usaha serta pengetahuan dasar atas keuangan untuk mencapai tujuan keuangan usaha. Dalam mengelola sebuah usaha perlu pengelolaan keuangan yang baik agar menghasilkan kinerja yang baik pula. Jika aspek keuangan semakin baik maka kinerja UMKM akan semakin naik (Wahyudiati \& Isroah, 2018). Berdasarkan uraian tersebut, maka dirumuskan hipotesis penelitian:

H1 : Pengelolaan keuangan berpengaruh positif pada kinerja UMKM.

Kompetensi seorang individu merupakan suatu yang melekat dalam dirinya yang dapat digunakan untuk memprediksi tingkat kinerjanya. Kompetensi sumber daya manusia adalah kompetensi yang berhubungan dengan pengetahuan, keterampilan, kemampuan dan karakteristik kepribadian yang berpengaruh secara langsung terhadap kinerjanya (Anwar, 2012). Kompetensi sumber daya manusia merupakan salah satu faktor yang berpengaruh pada kinerja UMKM. Hal ini dikarenakan sebuah unit usaha ditentukan oleh bagaimana individuindividu yang terlibat didalamnya mengelola usaha tersebut (Wahyudiati \& Isroah, 2018). Pada Penelitian (Ardiana et al., 2010; Fibriyani \& Mufidah, 2018) menemukan bahwa kompetensi sumber daya manusia berpengaruh positif pada kinerja UMKM. Semakin baik kompetensi sumber daya manusia maka semakin meningkat pula kinerja UMKM tersebut. Berdasarkan uraian tersebut, maka dirumuskan hipotesis penelitian:

H2 : Kompetensi sumber daya manusia berpengaruh positif pada kinerja UMKM..

Strategi pemasaran adalah upaya memasarkan suatu produk, baik itu barang atau jasa, dengan menggunakan pola rencana dan taktik tertentu sehingga jumlah penjualan menjadi lebih tinggi. Untuk dapat berkembang tentunya pelaku UMKM dituntut untuk kreatif dan inovatif dalam menyusun strategi pemasaran yang efektif agar menghasilkan kinerja yang bagus. Sebuah UMKM akan sulit untuk berkembang jika pelaku usahanya tidak mengetahui bagaimana cara memasarkan suatu produk yang efektif (Amalia, 2018). Penelitian (Purwaningsih \& Kusuma, 2015; Purwidianti \& Rahayu, 2015) menemukan 
bahwa strategi pemasaran berpengaruh positif pada kinerja UMKM. Semakin bagus strategi pemasaran UMKM makan kinerja UMKM akan semakin meningkat. Berdasarkan uraian tersebut, maka dirumuskan hipotesis penelitian:

H3 : Strategi pemasaran berpengaruh positif pada kinerja UMKM.

\section{III.METODE}

Penelitian ini dilakukan di UMKM yang berada di Kota Denpasar. Dipilihnya UMKM di Kota Denpasar karena Kota Denpasar merupakan pusat pergerakan sektor ekonomi di Bali dan dipilihnya sektor perdagangan karena sektor perdagangan jumlah pelakunya paling banyak daripada empat klasifikasi yang ada (bidang perdagangan, industri pertanian, industri non pertanian dan aneka jasa) sehingga dapat mengeneralisir populasi. Jenis data yang digunakan adalah data kualitatif yaitu persepsi responden mengenai variabel yang diuji. Berdasarkan sumbernya data yang digunakan adalah data primer berupa opini dari subyek penelitian yang dikumpulkan dengan menggunakan metode survei melalui kuesioner. Selanjutnya jawaban responden di skalakan dan dianalisis dengan metode analisis regresi linear berganda agar dapat di tarik kesimpulan. Responden yang digunakan dalam penelitian ini adalah pemilik UMKM sektor perdagangan yang merupakan UMKM binaan Dinas Koperasi Kota Denpasar yang berjumlah 9625 unit usaha. Dipilihnya sektor perdagangan karena sektor perdagangan jumlah pelakunya paling banyak daripada empat klasifikasi yang ada (bidang perdagangan, industri pertanian, industri non pertanian dan aneka jasa) sehingga dapat mengeneralisir populasi. Pengambilan sampel dalam penelitian ini dihitung menggunakan Rumus Slovin dengan taraf kesalahan 10\%. Jadi jumlah sampel yang digunakan adalah 99 pelaku UMKM. Teknik sampling yang digunakan dalam penelitian ini adalah menggunakan simple random sampling yaitu cara pemilihan sampel dengan pengambilan anggota sampel dari populasi dilakukan secara acak tanpa memperhatikan strata yang ada di dalam suatu populasi tersebut. Cara ini dilakukan karena anggota populasi dianggap homogen (Sugiyono, 2009).

Kesungguhan responden dalam menjawab kuisioner merupakan hal yang sangat penting, karena keabsahan (validitas) suatu hasil penelitian sangat ditentukan oleh alat ukur instrumen yang digunakan dan data yang diperoleh. Berdasarkan pertimbangan tersebut, dalam penelitian ini dilakukan pengujian apakah instrumen dan data penelitian berupa jawaban responden telah dijawab dengan benar atau tidak. Pengujian tersebut meliputi pengujian validitas dan pengujian reabilitas (keandalan). Teknik analisis data yang digunakan dalam penelitian ini adalah teknik analisis regresi linear berganda. Namun sebelumnya dilakukan uji asumsi klasik karena model regresi yang baik adalah model regresi yang terbebas dari masalah multikolonieritas, heteroskedastisitas, serta masalah normalitas data. Untuk itu maka perlu dilakukan pengujian terhadap model regresi yang akan digunakan pada penelitian.

\section{IV.HASIL DAN PEMBAHASAN}

Data pada penelitian ini diperoleh dengan menyebarkan kuesioner kepada responden sebanyak 99. Pendistribusian kuesioner dilakukan dengan cara mendatangi dan membagikan secara langsung kuesioner kepada mahasiswa yang akan dijadikan sampel dalam penelitian ini. Kuesioner yang dibagikan sebanyak 99 eksemplar, sesuai dengan jumlah sampel penelitian. Dari jumlah kuesioner yang disebarkan, 12 kuesioner tidak diisi dengan lengkap sehingga jumlah kuesioner yang dapat diolah adalah 87 .

Berdasarkan pengujian instrumen dilihat bahwa koefisien korelasi butir-butir pertanyaan dari semua variabel dalam kuesioner adalah valid, hal ini terlihat dari nilai pearson correlation dari masing-masing variabel memiliki nilai di atas 0,3 dan instrumen dinyatakan reliabel karena nilai cronbach alpha dari masing-masing variabel menunjukkan nilai di atas 0,70. Sebelum melakukan analisis regresi linear berganda, terlebih dahulu dilakukan pengujian asumsi klasik. Berdasarkan pengujian asumsi klasik diketahui bahwa variabel penelitian berdistribusi normal serta terbebas dari masalah multikolonieritas dan heteroskedastisitas.

Untuk menguji hipotesis penelitian ini menggunakan analisis regresi linear berganda. Hasil uji regresi linear berganda dapat dilihat dalam tabel 1: 
Tabel 1

Hasil Analisis Regresi Linear Berganda

\begin{tabular}{|c|c|c|c|c|c|}
\hline \multirow{2}{*}{ Variabel } & \multicolumn{2}{|c|}{ Unstandardized Coefficient } & \multirow{2}{*}{$\frac{\text { Standardized }}{\text { Beta }}$} & \multirow{2}{*}{$\mathbf{t}$} & \multirow{2}{*}{ Sig } \\
\hline & $\mathrm{B}$ & Std. Error & & & \\
\hline Constant & 0,312 & 1,619 & & 0.193 & 0,848 \\
\hline Pengelolaan Keuangan & 0,552 & 0,152 & 0,543 & 3,630 & 0,000 \\
\hline Kompetensi SDM & 0,080 & 0,038 & 0,096 & 2,095 & 0,039 \\
\hline Strategi Pemasaran & 0,309 & 0,132 & 0,354 & 2,338 & 0,022 \\
\hline \multicolumn{6}{|c|}{ Adjusted Rsquare : 0,838} \\
\hline \multicolumn{6}{|c|}{ F hitung : 149,364 } \\
\hline \multicolumn{6}{|c|}{ Sig. F hitung : 0,000 } \\
\hline
\end{tabular}

Sumber: Data diolah, 2019

Berdasarkan Tabel 1 di atas, maka persamaan analisis regresi linier bergandanya adalah sebagai berikut:

$$
\mathrm{Y}=0,543 \mathrm{X} 1+0,096 \mathrm{X} 2+0,354 \mathrm{X} 3+\varepsilon
$$

Interpretasi dari persamaan analisis regresi linier berganda di atas adalah sebagai berikut:

Nilai koefisien regresi pengelolaan keuangan $\left(\mathrm{X}_{1}\right)$ sebesar 0,543 menunjukkan bahwa setiap kenaikan pengelolaan keuangan akan meningkatkan kinerja UMKM sebesar 54,3\%.

Nilai koefisien regresi kompetensi sumber daya manusia $\left(\mathrm{X}_{2}\right)$ sebesar 0,096 menunjukkan bahwa setiap kenaikan tingkat kompetensi sumber daya manusia akan meningkatkan kinerja UMKM sebesar 9,6\%.

Nilai koefisien regresi strategi pemasaran $\left(\mathrm{X}_{3}\right)$ sebesar 0,354 menunjukkan bahwa setiap kenaikan tingkat strategi pemasaran akan meningkatkan kinerja UMKM sebesar 35,4\%.

Sebelum model regresi digunakan untuk menguji hipotesis, maka terlebih dahulu dilihat kelayakan model regresi yang dapat dilihat melalui nilai signifikansi uji $\mathrm{F}$ dan adjusted $\mathrm{R}^{2}$. Berdasarkan hasil regresi linear berganda pada Tabel 5.7, Uji F-test dengan uji Anova, diperoleh tingkat signifikansi sebesar 0,000 lebih kecil dari $\alpha=0,05$. Nilai tingkat signifikansi tersebut menunjukkan bahwa model persamaan regresi dalam penelitian ini layak untuk digunakan.

Dapat dilihat pada kolom Adjusted $R$ Square di Tabel 1 di atas menunjukkan nilai 0,838. Hal ini menunjukkan bahwa variabel-variabel independen memberikan kontribusi sebesar 0,838 atau $83,8 \%$ terhadap variabel dependennya. Sedangkan sisanya sebesar $16,2 \%$ dipengaruhi oleh variabel lain yang tidak terdapat dalam model persamaan regresi yang digunakan dalam penelitian ini.

Berdasarkan hasil uji t pada Tabel 1 yang merupakan pengujian hipotesis maka dapat dijelaskan pengaruh masing-masing variabel, serta menjawab hipotesis penelitian yang telah dirumuskan sebelumnya. Pengujian dilakukan dengan menggunakan tingkat signifikansi 5\% $(0,05)$.

Pengaruh pengelolaan keuangan pada kinerja UMKM.

Hipotesis pertama menyatakan bahwa pengelolaan keuangan berpengaruh positif pada kinerja UMKM. Berdasarkan Tabel diatas, dapat dilihat bahwa hasil uji $t$ terhadap variabel pengelolaan keuangan $\left(\mathrm{X}_{1}\right)$ diperoleh nilai signifikansi $\mathrm{t}$ sebesar 0,000 dan nilai koefisien regresi (Beta) positif 0,543. Nilai signifikansi pengelolaan keuangan sebesar $0,000<0,05$ maka $\mathrm{H}_{1}$ diterima. Hal ini berarti pengelolaan keuangan berpengaruh positif pada kinerja UMKM. Semakin bagus pengelolaan keuangan yang dilakukan oleh pelaku UMKM maka kinerjanyapun akan semakin meningkat. Pengelolaan keuangan adalah segala aktivitas yang berhubungan dengan perolehan, pendanaan dan pengelolaan aktiva dengan beberapa tujuan menyeluruh. Profesionalisme dalam pengelolaan keuangan akan membantu pelaku usaha terkait dengan pengelolaan usaha dimulai dari anggaran, perencanaan simpanan dana usaha serta 
pengetahuan dasar atas keuangan untuk mencapai tujuan keuangan usaha. Dalam mengelola sebuah usaha perlu pengelolaan keuangan yang baik agar menghasilkan kinerja yang baik pula. Hasil penelitian ini mendukung penelitian yang dilakukan oleh Wahyudiati dan Isroah (2018), Hartati (2013), Anggraeni, (2015) yang menyatakan bahwa kinerja UMKM sangat dipengaruhi oleh pengelolaan keuangan. Jika aspek keuangan semakin baik maka kinerja UMKM akan semakin naik.

Pengaruh kompetensi sumber daya manusia pada kinerja UMKM.

Hipotesis kedua menyatakan bahwa kompetensi sumber daya manusia berpengaruh positif pada kinerja UMKM. Berdasarkan Tabel 5.7, dapat dilihat bahwa hasil uji t terhadap variabel kompetensi sumber daya manusia $\left(\mathrm{X}_{2}\right)$ diperoleh nilai signifikansi t sebesar 0,039 dan nilai koefisien regresi (Beta) positif 0,096. Nilai signifikansi kompetensi sumber daya manusia sebesar $0,039<0,05$ maka $\mathrm{H}_{2}$ diterima. Hal ini berarti kompetensi sumber daya manusia berpengaruh positif pada kinerja UMKM. Semakin tinggi kompetensi sumber daya manusia maka kinerja UMKM akan semakin meningkat. Kompetensi seorang individu merupakan suatu yang melekat dalam dirinya yang dapat digunakan untuk memprediksi tingkat kinerjanya. Kompetensi sumber daya manusia adalah kompetensi yang berhubungan dengan pengetahuan, keterampilan, kemampuan dan karakteristik kepribadian yang berpengaruh secara langsung terhadap kinerjanya. Hasil penelitian ini mendukung penelitian yang dilakukan oleh Wahyudiati dan Isroah (2018), Fibriyani dan Mufidah (2018) dalam penelitiannya menemukan bahwa kompetensi sumber daya manusia berpengaruh positif pada kinerja UMKM. Semakin baik kompetensi sumber daya manusia maka semakin meningkat pula kinerja UMKM tersebut.

Pengaruh strategi pemasaran pada kinerja UMKM.

Hipotesis ketiga menyatakan bahwa strategi pemasaran berpengaruh positif pada kinerja UMKM. Berdasarkan Tabel 5.7, dapat dilihat bahwa hasil uji $t$ terhadap variabel strategi pemasaran $\left(\mathrm{X}_{3}\right)$ diperoleh nilai signifikansi $\mathrm{t}$ sebesar 0,022 dan nilai koefisien regresi (Beta) positif 0,354 . Nilai signifikansi strategi pemasaran sebesar $0,022<0,05$ maka $\mathrm{H}_{3}$ diterima. Hal ini berarti strategi pemasaran berpengaruh positif pada kinerja UMKM. Ini menunjukkan bahwa semakin bagus strategi pemasaran yang dilakukan maka kinerja UMKM akan semakin meningkat. Strategi pemasaran adalah upaya memasarkan suatu produk, baik itu barang atau jasa, dengan menggunakan pola rencana dan taktik tertentu sehingga jumlah penjualan menjadi lebih tinggi. Untuk dapat berkembang tentunya pelaku UMKM dituntut untuk kreatif dan inovatif dalam menyusun strategi pemasaran yang efektif agar menghasilkan kinerja yang bagus. Sebuah UMKM akan sulit untuk berkembang jika pelaku usahanya tidak mengetahui bagaimana cara memasarkan suatu produk yang efektif. Hasil penelitian ini mendukung penelitian yang dilakukan oleh Amalia (2018), Purwaningsih dan Pajar (2015) dan Purwidianti (2015) dalam penelitianya menemukan bahwa strategi pemasaran berpengaruh positif pada kinerja UMKM. Semakin bagus strategi pemasaran UMKM makan kinerja UMKM akan semakin meningkat.

\section{SIMPULAN}

Berdasarkan permasalahan penelitian, tujuan, hipotesis dan hasil pembahasan pada bab sebelumnya, maka dapat disimpulkan Pengelolaan keuangan berpengaruh positif pada kinerja UMKM. Hal ini menunjukkan bahwa semakin bagus pengelolaan keuangan yang dilakukan oleh pelaku UMKM maka kinerja usahanyapun akan semakin meningkat. Kompetensi sumber daya manusia berpengaruh positif pada kinerja UMKM. Hal ini menunjukkan bahwa semakin tinggi kompetensi yang dilakukan oleh individu dalam menjalankan usaha maka akan meningkatkan kinerja dari perusahaanya. Strategi pemasaran berpengaruh positif pada kinerja UMKM. Hal ini menunjukkan bahwa semakin bagus strategi pemasaran yang diterapkan oleh pelaku UMKM maka semakin bagus pula kinerja dari perusahaannya.

\section{DAFTAR PUSTAKA}

Amalia, E. (2018). Implementasi Program Usaha Mikro Kecil dan Menengah (UMKM) Di Kecamatan Ciseeng, Kab. Bogor, Provinsi Jawa Barat. Universitas Pamulang, Tangerang Selatan.

Anggraeni, B. D. (2015). Pengaruh Tingkat Literasi Keuangan Pemilik Usaha Terhadap Pengelolaan Keuangan. Studi Kasus: Umkm Depok. Jurnal Vokasi Indonesia , 3(1), 22-30. Retrieved from http:// www.jvi.ui.ac.id/index.php/jvi/article/view/23 
Anwar, M. P. (2012). Perencanaan dan Pengembangan Sumber Daya Manusia. Bandung: Refika Aditama.

Ardiana, I. D. K. R., Brahmayanti, I. A., \& Subaedi. (2010). Kompetensi SDM UKM dan Pengaruhnya Terhadap Kinerja UKM di Surabaya. Jurnal Manajemen Dan Kewirausahaan, 12(1), 42-55. Retrieved from https://doi.org/10.9744/jmk.12.1.pp. 42-55

Azwar, S. (2010). Sikap Manusia Teori dan Pengukurannya. Yogyakarta: Pustaka Pelajar.

Fibriyani, V., \& Mufidah, E. (2018). Pengaruh Faktor Eksternal Dan Internal Terhadap Kinerja Usaha Mikro Kecil Dan Menengah Di Kota Pasuruan. In Conference on Innovation and Application of Science and Technology (pp. 148-157). Retrieved from http://publishing-widyagama.ac.id/ejournal-v2/ index.php/ciastech/article/view/618

Krisdanti, G., \& Rodhiyah, R. (2016). Analisis Faktor-Faktor Yang Mempengaruhi Kinerja Ukm Pada Sektor Industri Pengolahan Makanan Di Kota Semarang. Jurnal Ilmu Administrasi Bisnis, 5(4). Retrieved from https://ejournal3.undip.ac.id/index.php/jiab/ article/view/13379

Purwaningsih, R., \& Kusuma, P. D. (2015). Analisis FaktorFaktor Yang Mempengaruhi Kinerja Usaha Kecil Dan Menengah (UKM) Dengan Metode Structural Equation Modeling (Studi kasus UKM berbasis Industri Kreatif Kota Semarang). In Prosiding Seminar Nasional Sains dan Teknologi (pp. 7-12) Retrieved from https:// publikasiilmiah.unwahas.ac.id/index.php/ PROSIDING_SNST_FT/article/view/1113

Purwidianti, W., \& Rahayu, T. S. M. (2015). Pengaruh Faktor Internal Dan Eksternal Terhadap Kinerja Usaha Industri Kecil Dan Menengah Di Purwokerto Utara. Kinerja: Journal Business and Economics, 19 (2), 149-159.

Ratnawati, A. T., \& Hikmah. (2013). Faktor-Faktor Yang Mempengaruhi Kinerja UKM (Studi Kasus UKM Di Kabupaten dan Kota Semarang). E-Jurnal Serat Acitya, 2(1), 102-114. Retrieved from http:// jurnal.untagsmg.ac.id/index.php/sa/article/view/41

Sarlito, S. W., \& Meinarno, E. A. (2009). Psikologi Sosial. Jakarta: Salemba Harmonika.

Sugiyono. (2009). Metode Penelitian Kuantitatif, Kualitatif, dan R\&D. Bandung: PT. Alfabeta.

Tang, T., \& Chen, Y.-J. (2008). Intelligence Vs. Wisdom: The Love of Money, Machiavellianism, and Unethical Behavior across College Major and Gender. Journal of Business Ethics, 82(1), 1-26. Retrieved from https://econpapers.repec.org/article/ kapjbuset/v_3a82_3ay_3a2008_3ai_3a1_3ap_3a126.htm

Wahyudiati, D., \& Isroah. (2018). Pengaruh Aspek Keuangan Dan Kompetensi Sumber Daya Manusia (SDM) Terhadap Kinerja Usaha Mikro Kecil Dan Menengah (UMKM) Di Desa Kasongan. Profita: Kajian Ilmu Akuntansi, 6(2), 1-11. Retrieved from http://journal.student.uny.ac.id/ojs/index.php/profita/ article/view/13761 